\title{
Fungitoxic Potentialities of NECO 50 EC in an Integrated Black Sigatoka Management Strategy in Industrial Dessert Banana Plantation
}

\author{
Jean-Martial F. K. Kassi, Henri P. N'Guessan, Seydou Tuo, Brahima Camara, and Daouda Koné
}

\section{ABSTRACT}

Black leaf streak disease (BLSD) is the major constraint on banana production around the world. In Côte d'Ivoire, this disease is found in all banana-growing areas and its management involves the use of large volumes of agrochemicals. This mode of production is increasingly denounced by consumers from regarding fruit contamination by phytopharmaceuticals. The objective of this study is to promote the use of NECO $50 \mathrm{EC}$, a plant extract-based biofungicide in an integrated black Sigatoka management system. The fungitoxic effect of NECO $50 \mathrm{EC}$ was assessed in vitro on Mycosphaerella fijiensis conidia germination and the evolution of black leaf streak disease symptoms under natural infestation. NECO $50 \mathrm{EC}$ was applied over a surface area of 25 ha at a rate of $0.3 \mathrm{l} / \mathrm{ha}$. Its weekly effect on the evolution of the rank of the youngest leaf affected (YLA), the rank of the youngest necrotic leaf (YLN), the number of functional leaves at flowering (NFLF) and the number of functional leaves at harvest (NFLH) was determined and then compared to those of a morpholine (Volley $88 \mathrm{OL}$ ) applied over a surface area of 25 ha at a dose of $0.5 \mathrm{l} / \mathrm{ha}$. NECO $50 \mathrm{EC}$ showed an anti-germinating effect on Mycosphaerella fijiensis conidia at low doses, useful in reducing disease spreading. Its application in banana tree plantations reduced disease pressure on the plots. It ensured the protection of new leaves generated (YLA > 4), favored ranks of YLN greater than 9. More than 14 leaves were counted at flowering and more than 7 leaves at harvest were observed.

NECO 50 EC, a plant extract-based biological fungicide, may be an effective alternative for black leaf streak disease control in industrial banana tree plantations.

Keywords: Banana, Black Leaf Streak Disease, Mycosphaerella fijiensis, Control, NECO 50 EC.
Published Online: August 31, 2021

ISSN: $2684-5199$

DOI: 10.24018 /ejbio.2021.2.4.232

J-M. F. K. Kassi*

Félix HOUPHOUËT-BOIGNY

University, UFR Biosciences Laboratory of Agricultural Biotechnology and Valorization of Natural Resources, Abidjan, Côte d'Ivoire.

(e-mail: fernand2kassi@yahoo.fr)

H. P. N'Guessan

Félix HOUPHOUËT-BOIGNY University, UFR Biosciences Laboratory of Agricultural Biotechnology and Valorization of Natural Resources, Abidjan, Côte d'Ivoire.

(e-mail: nphenri ${ }^{\circledR}$ yahoo.fr)

S. Tuo

Félix HOUPHOUËT-BOIGNY

University, UFR Biosciences Laboratory of Agricultural Biotechnology and Valorization of Natural Resources, Abidjan, Côte d'Ivoire.

(e-mail: tuoseydou4@yahoo.fr)

B. Camara

Félix HOUPHOUËT-BOIGNY

University, UFR Biosciences Laboratory

of Agricultural Biotechnology and Valorization of Natural Resources, Abidjan, Côte d'Ivoire.

(e-mail: camara_ib@yahoo.fr)

D. Koné

Félix HOUPHOUËT-BOIGNY

University, UFR Biosciences Laboratory of Agricultural Biotechnology and Valorization of Natural Resources, Abidjan, Côte d'Ivoire.

(e-mail: daoudakone2013@gmail.com)

*Corresponding Author

\section{INTRODUCTION}

In agriculture, fungal diseases are responsible for almost half of the pathologies recorded in plants and the resulting annual yield losses amount to several million tons [1]. In banana trees, black Sigatoka or Black Leaf Streak Disease (BLSD) is the leaf disease which is the most damaging to yield worldwide [2]. In Côte d'Ivoire, this disease, detected in 1985 in Sud-Comoé [3], is now found in all bananagrowing areas [4]. The damage caused by this disease results in yield losses of up to $100 \%$ and causes premature ripening of bananas [5]. In order to fight effectively against the parasite, synthetic fungicides from the benzimidazole, triazole and strobulurin families are mainly used [6]. The exclusive and excessive use of these fungicides in the case of fungal infection by Mycosphaerella fijiensis has developed resistance foci in certain areas [7] and is the major cause of chemical residue accumulation in the fruits at harvest [8]. End consumers are becoming more demanding on the sanitary quality of food [9] and more particularly on 
production methods regarding phytopharmaceuticals [10], [11]. The competitiveness of Ivorian bananas on international markets therefore requires a production method that limits the use of chemical pesticides.

The development of natural products with pesticide activities appears to be one of the solutions for agricultural product-producing and exporting countries [12]. This option raises a lot of hope for the banana sector in Côte d'Ivoire, especially since it is one of the largest consumers of agrochemicals for its cultivation [13]. The objective of this study is to promote the use of NECO $50 \mathrm{EC}$, a biofungicide based on plant extracts from the Ivorian flora, in an integrated black Sigatoka management system. The effectiveness of NECO 50 EC will be assessed both under in vitro cultivation conditions on Mycosphaerella fijiensis conidia germination and under natural infestation conditions on black Sigatoka symptom control.

\section{MATERIAL AND METHODS}

\section{A. In vitro Effect of NECO 50 EC on Mycosphaerella} Fijiensis Conidia Germination

The inhibitory effect of NECO 50 EC on Mycosphaerella fijiensis conidia germination is tested in comparison with that of three active ingredients (pyraclostrobin, fenpropimorph, propiconazole) by incorporation into agar culture medium. Thus, different culture media at doses of $1 \mu \mathrm{l} / \mathrm{L}$ (T1); $5 \mu \mathrm{l} / \mathrm{L}$ (T2); $10 \mu \mathrm{l} / \mathrm{L}$ (T3); $100 \mu \mathrm{l} / \mathrm{L}$ (T4); $150 \mu \mathrm{l} / \mathrm{L}$ (T5); $200 \mu \mathrm{l} / \mathrm{L}$ (T6); $250 \mu \mathrm{l} / \mathrm{L}$ (T7); $300 \mu \mathrm{l} / \mathrm{L}$ (T8); $350 \mu \mathrm{l} / \mathrm{L}$ (T9); $400 \mu \mathrm{l} / \mathrm{L}$ (T10); $450 \mu \mathrm{l} / \mathrm{L}$ (T11) and $500 \mu \mathrm{l} / \mathrm{L}$ (T12) of NECO 50 EC were prepared.

Likewise, 3 culture media containing active ingredients of synthetic fungicides respectively at doses of $0.1 \mu \mathrm{l} / \mathrm{l}$ of propiconazole (T13); $0.1 \mu \mathrm{l} / 1$ of fenpropimorph (T14) and 1 $\mu \mathrm{l} / \mathrm{l}$ of pyraclostrobin (T15) were prepared from $100 \mathrm{ml}$ of stock solutions of these synthetic fungicides. They were obtained by diluting the stock solution prepared by dissolving the commercial product in sterile distilled water. The Mycosphaerella fijiensis conidia originated from necrotic spots on plantain tree leaves, taken from the experimental site of the University Félix Houphouët-Boigny of Cocody (Côte d'Ivoire). The sampling involved at least 16 banana tree plants and a single leaf fragment with black leaf streak disease stage 2 or 3 lesions was taken per plant.

The Petri dishes containing the agar media, amended or not, were subdivided at their base into 16 sections. Each section numbered 1 to 16 received a fragment of the 16 leaves, respectively, cut from black leaf streak disease stage 2 or 3 lesion (Fig. 1 A). The conidia found on these leaf fragments were transferred to the culture medium by trapping (Fig. 1 B). The Petri dishes were then incubated in a culture chamber at room temperature for $48 \mathrm{~h}$ and under a 12-h photoperiod.

Images of germinating conidia were taken in each dish and in each of the 16 sections using an optical microscope equipped with a camera (AmScope).

From these images, and using ToupView 3.7 software, germ tube elongation of 10 conidia, on average, was assessed per section.
In total, germ tube elongation of 160 conidia per petri dish was assessed. The conidia in the control Petri dishes were also assessed under the same conditions without NECO 50 EC or synthetic fungicide. The experiment was repeated 3 times over time.

The sensitivity of Mycosphaerella fijiensis conidia to different doses of NECO 50 EC and synthetic fungicides was assessed by calculating the average elongation of germ tubes in each amended Petri dish.

The germ tube elongation reduction rate (TRA) of each product was calculated according to the following formula:

$$
T R A=\frac{(T-E)}{T} \times 100
$$

where

$\mathrm{T}=$ average elongation of the germ tube of growing conidia on culture medium without amendment $(\mu \mathrm{m})$;

$\mathrm{E}=$ average elongation of the germ tube of growing conidia on culture medium at a concentration $\mathrm{C}$ of NECO $50 \mathrm{EC}$ or synthetic fungicides $(\mu \mathrm{m})$.
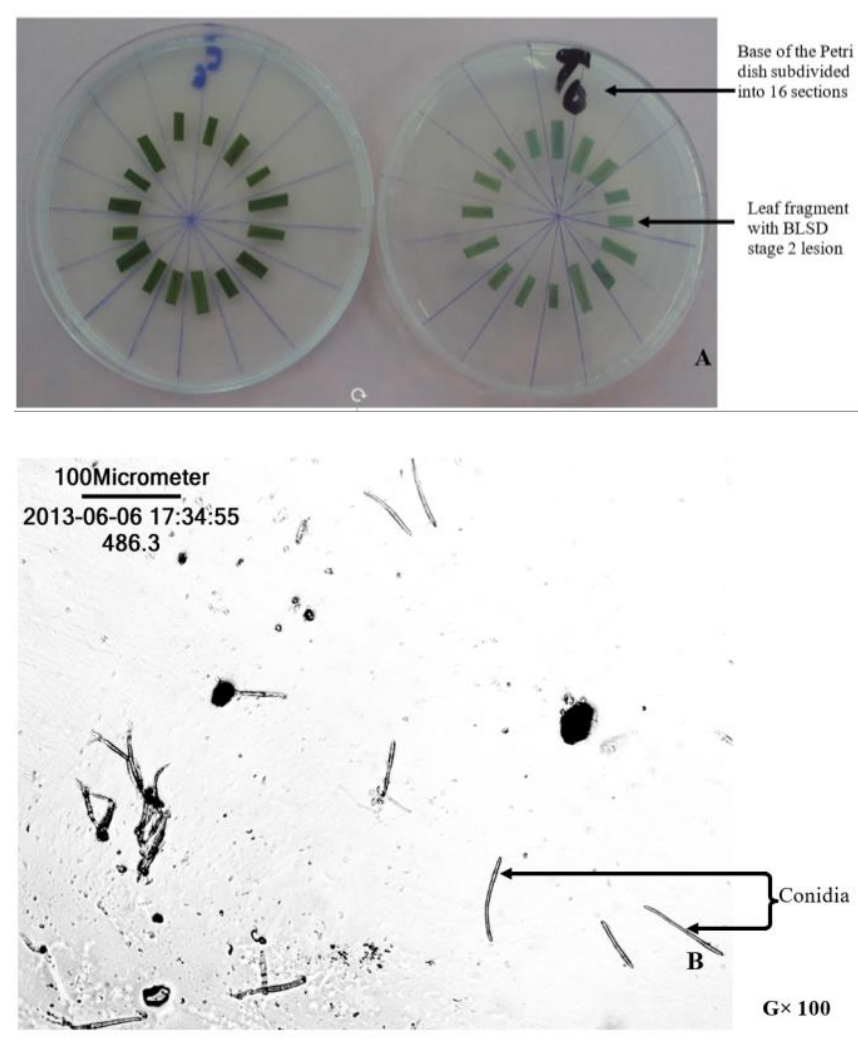

Fig. 1. Trapping and culturing of Mycosphaerella fijiensis conidia: A: Trapping of Mycosphaerella fijiensis conidia on culture media, B: Conidia trapped on culture media amended with fungicides or NECO 50EC.

\section{B. In vivo effect of NECO 50 EC on the Evolution of Black Sigatoka Epidemiological Factors}

\section{Study site}

The study was conducted under conditions of natural Mycosphaerella fijiensis infestation in the new dessert banana production area of BBSA (Bananière de Bandama $\mathrm{SA}$ ) located in the Hambol region in northern of Côte d'Ivoire. The experimental site is located between $08^{\circ} 46^{\prime}$ 12.82" North latitude and $005^{\circ} 29^{\prime} 0.11^{\prime \prime}$ West longitude, 
with an average temperature of $26.8^{\circ} \mathrm{C}$ and a total rainfall of $917 \mathrm{~mm}$ recorded during the experiment.

\section{Methodology}

NECO 50 EC, concentrated emulsion, was applied over a surface area of 25 ha of banana tree plantation of the William variety at a dose of $0.3 \mathrm{l} / \mathrm{ha}$ in a mineral oil-based mixture (Banole). Its weekly effect on the evolution of some black Sigatoka phytopathological descriptors, namely the rank of the youngest leaf affected (YLA) according to [14] and the rank of the youngest necrotic leaf (YLN) according to [15]. The number of functional leaves at flowering (NFLF) and the number of functional leaves at harvest (NFLH) were the productivity factors assessed. These parameters were then compared with those collected over 25 ha of banana tree plantation treated with Volley 88 OL (morpholine) at a dose of $0.5 \mathrm{l} / \mathrm{ha}$ [16] in a mineral oil-based mixture (Banole). The first treatments were carried out 7 days after planting under thermal conditions below $30^{\circ} \mathrm{C}$ with a ULM type aircraft, with a capacity of $100 \mathrm{~L}$. In total, 10 applications of NECO $50 \mathrm{EC}$ and Volley $88 \mathrm{OL}$ were carried out on the different plots in weeks $1 ; 4 ; 8 ; 11 ; 14 ; 26 ; 30 ; 34 ; 36$ and 39 . The observations of pathological parameters (YLA, YLN, EE) and productivity parameters (NFLF, NFLH) were carried out over 6 different observation stations per plot treated for 46 weeks. Each observation point made up of 10 banana trees was arranged on a $1000 \mathrm{~m}^{2}$ board. Each rectangular-shaped board consisted of 2 double rows of plants separated by $3 \mathrm{~m}$ with $1.70 \mathrm{~m}$ between the rows of plants and $2.20 \mathrm{~m}$ between the plants in a row. The 10 banana trees per observation point were monitored regularly until harvest.

\section{Statistical analyses}

One-criterion variance analysis (ANOVA I) was used to assess the in vitro effect of the different treatments on the elongation of Mycosphaerella fijiensis conidia germ tubes and in vivo on the evolution of black Sigatoka phytopathological descriptors and banana productivity factors. The Newman-Keuls test made it possible to compare the average $\alpha$ risk values of $5 \%$ in order to classify the different treatments according to their fungitoxicity and their ability to delay the evolution of black Sigatoka symptoms. Statistical analyses of the data were carried out with STATISTICA version 7.1 software.

\section{RESULtS}

\section{A. Effect of Treatments on Mycosphaerella Fijiensis Germ Tube Elongation}

The measurement of germ tube elongation carried out 48 $\mathrm{h}$ after the culturing of Mycosphaerella fijiensis conidia, on the media incorporated with NECO 50 EC at different doses and synthetic fungicides, showed a reduction effect of the germ tube until its total inhibition (Fig. 2). The effects were different depending on the doses of NECO 50 EC and the synthetic fungicides used. On culture media amended with NECO $50 \mathrm{EC}$, the T1 $(1 \mu \mathrm{l} / \mathrm{L}), \mathrm{T} 2(5 \mu \mathrm{l} / \mathrm{L})$ and T3 $(10 \mu \mathrm{l} / \mathrm{L})$ treatments resulted in the lowest germ tube reduction rates. This reduction became more significant and reached 86.80 pc in $\mathrm{T} 4(100 \mu \mathrm{l} / \mathrm{L})$ treatment, then increased to reach 94.50 pc, $98.90 \mathrm{pc}, 99.10 \mathrm{pc}$ and $99.50 \mathrm{pc}$ respectively, for T5 (150 $\mu \mathrm{l} / \mathrm{L}) ; \mathrm{T} 6(200 \mu \mathrm{l} / \mathrm{L}) ; \mathrm{T} 7(250 \mu \mathrm{l} / \mathrm{L}) ; \mathrm{T} 8(300 \mu \mathrm{l} / \mathrm{L})$ and T9 $(350 \mu \mathrm{l} / \mathrm{L})$ treatments. The maximum reduction $(100 \mathrm{pc})$ was obtained with T10 $(400 \mu \mathrm{l} / \mathrm{L})$; T11 $(450 \mu \mathrm{l} / \mathrm{L})$ and T12 (500 $\mu \mathrm{l} / \mathrm{L})$ treatments.

Cultured conidia behaved differently with respect to synthetic fungicides. Treatment T15 (pyraclostrobin) caused a complete reduction in germ tube elongation. In contrast, the reduction in germination with T13 (propiconazole) and $\mathrm{T} 14$ (fenpropimorph) treatments varied from 51.20 to 63.10 pc.

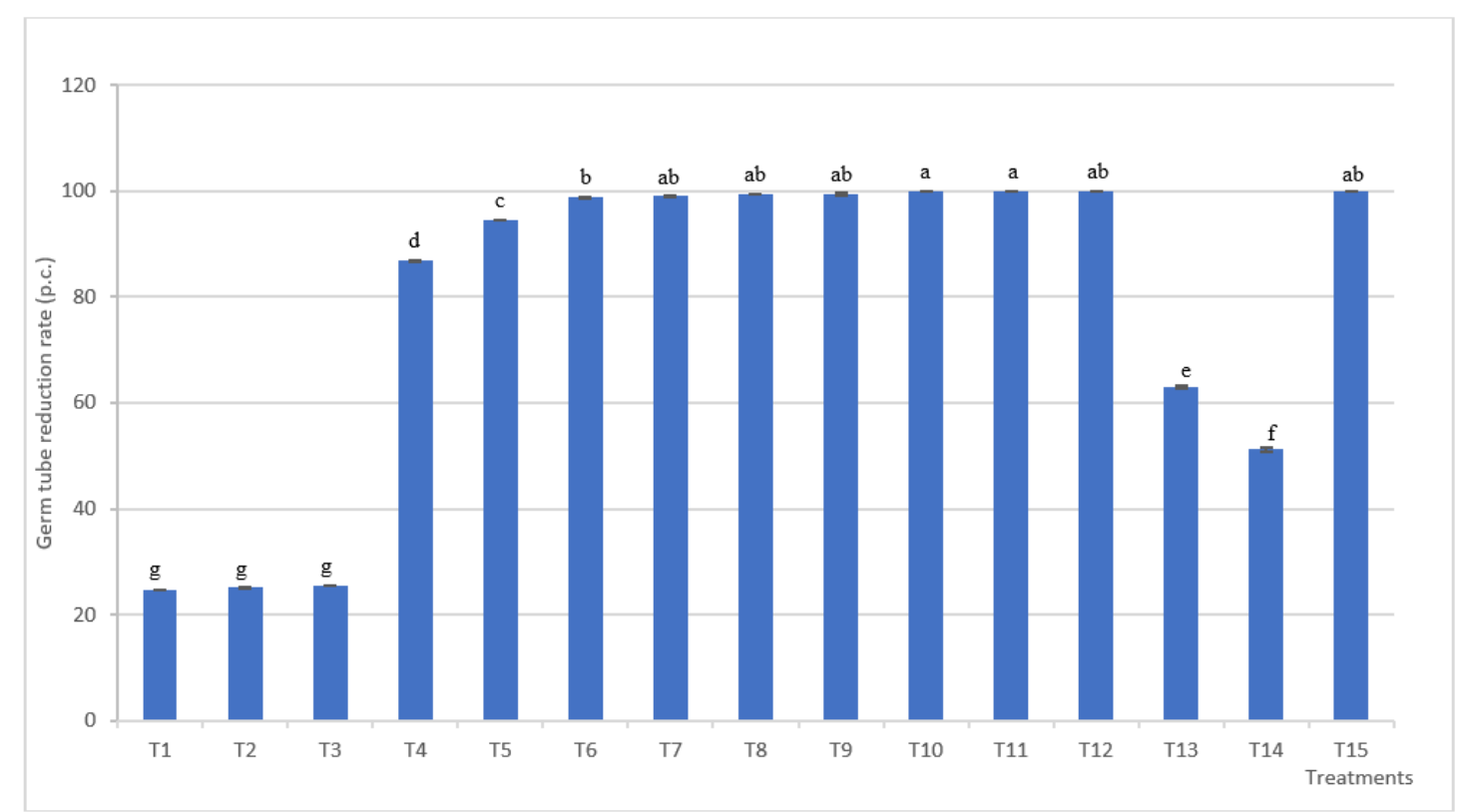

Fig. 2: Germ tube elongation of Mycosphaerella fijiensis conidia on agar medium amended at different doses of NECO 50 EC and synthetic fungicides $\mathrm{T}_{1}$ : NECO $50 \mathrm{EC}$ at $1 \mu \mathrm{l} / \mathrm{L} ; \mathrm{T}_{2}$ : NECO $50 \mathrm{EC}$ at $5 \mu \mathrm{l} / \mathrm{L} ; \mathrm{T}_{3}: \mathrm{NECO} 50 \mathrm{EC}$ at $10 \mu \mathrm{l} / \mathrm{L} ; \mathrm{T}_{4}: \mathrm{NECO} 50 \mathrm{EC}$ at $100 \mu \mathrm{l} / \mathrm{L} ; \mathrm{T}_{5}: \mathrm{NECO} 50 \mathrm{EC}$ at $150 \mu \mathrm{l} / \mathrm{L} ; \mathrm{T}_{6}$ : NECO $50 \mathrm{EC}$ at $200 \mu \mathrm{l} / \mathrm{L} ; \mathrm{T}_{7}: \mathrm{NECO} 50 \mathrm{EC}$ at $250 \mu \mathrm{l} / \mathrm{L} ; \mathrm{T}_{8}: \mathrm{NECO} 50 \mathrm{EC}$ at $300 \mu \mathrm{l} / \mathrm{L} ; \mathrm{T}_{9}: \mathrm{NECO} 50 \mathrm{EC}$ at $350 \mu \mathrm{l} / \mathrm{L} ; \mathrm{T}_{10}: \mathrm{NECO} 50 \mathrm{EC}$ at $400 \mu \mathrm{l} / \mathrm{L}$; $\mathrm{T}_{11}$ : NECO $50 \mathrm{EC}$ at $450 \mu \mathrm{l} / \mathrm{L} ; \mathrm{T}_{12}$ : NECO $50 \mathrm{EC}$ at $500 \mu \mathrm{l} / \mathrm{L} ; \mathrm{T}_{13}$ : propiconazole at $0,1 \mu \mathrm{l} / \mathrm{L} ; \mathrm{T}_{14}$ : fenpropimorph at $0,1 \mu \mathrm{l} / \mathrm{L} ;$ et $\mathrm{T}_{15}:$ pyraclostrobin at 1 $\mu \mathrm{l} / \mathrm{L}$. The histograms followed by the same letter are not significantly different (Newman-keuls test at 5 pc threshold). 


\section{B. Effect of treatments on black Sigatoka epidemiological variables}

\section{Effect on black Sigatoka evolution status (EE)}

The two fungicides, NECO $50 \mathrm{EC}$ and Volley $88 \mathrm{OL}$ showed a significant effect in slowing black Sigatoka evolution (Fig. 3). However, differences in effectiveness were observed at different periods of the assessment. The fungicide treatments carried out at weeks $1 ; 4 ; 8 ; 10$ and 14 favored a gradual fall in the level of the disease until it was eliminated at S19 on the plots treated with Volley. During the same period the level of the disease remained constant and nil on the plots treated with NECO 50 EC until week 23. The period from week 26 to week 46 was characterized by strong variations in black Sigatoka evolution, highest precipitation heights and frequencies. On the plots treated with NECO 50 EC, a sudden increase in the level of the disease was observed as from week 26 to reach the peak of 428.66 at week 32 . Following the treatment carried out at weeks 30 and 32, a gradual fall in the level of the disease was observed until reaching 27.16 at week 37. A second phase of increase in the level of black Sigatoka was seen from week 38 and reached the peak of 314.83 at week 40 before experiencing a regression phase down to 118.83 at week 42 following the treatment carried out at week 40 .

On the plots treated with volley, from week 26 to week 46, the disease level evolution curve was similar to the one observed on the plots treated with NECO 50 EC but with less significant peak heights. Maximum disease level values were 363.50 and 193.83 at weeks 32 and 40, respectively.

\section{Effect on some key phytopathological descriptors of} black Sigatoka and banana tree productivity factors

The rank of the youngest leaf affected (YLA), that of the youngest necrotic leaf (YLN), the number of functional leaves at flowering (NFLF) and the number of functional leaves at harvest (NFLH) were assessed daily on the plots treated with NECO 50 EC and Volley 88 OL. The analysis of the results revealed a statistically significant difference between treatments for each of the variables depending on the assessment period (Table I). Thus, the average rank of the youngest leaf affected (YLA) was significantly higher from week 1 to week 19 on the plot treated with NECO 50 EC. It was identical from week 20 to week 23 and from week 32 to week 46 for both treatments. Regarding the average rank of the YLN, a significant difference was observed between both treatments, the average values varied from 9.05 to 14.08 and from 11.01 to 13.93 on the plots treated with NECO 50 EC and Volley 88 OL, respectively. Concerning the number of leaves counted at flowering (NFLF) from week 16, the average values ranged from 11.18 to 13.90 with the NECO 50 EC treatment and from 11.40 to 13.95 with the Volley 88 OL treatment. At harvest, the number of functional leaves was statistically higher on the plots treated with Volley 88 OL.

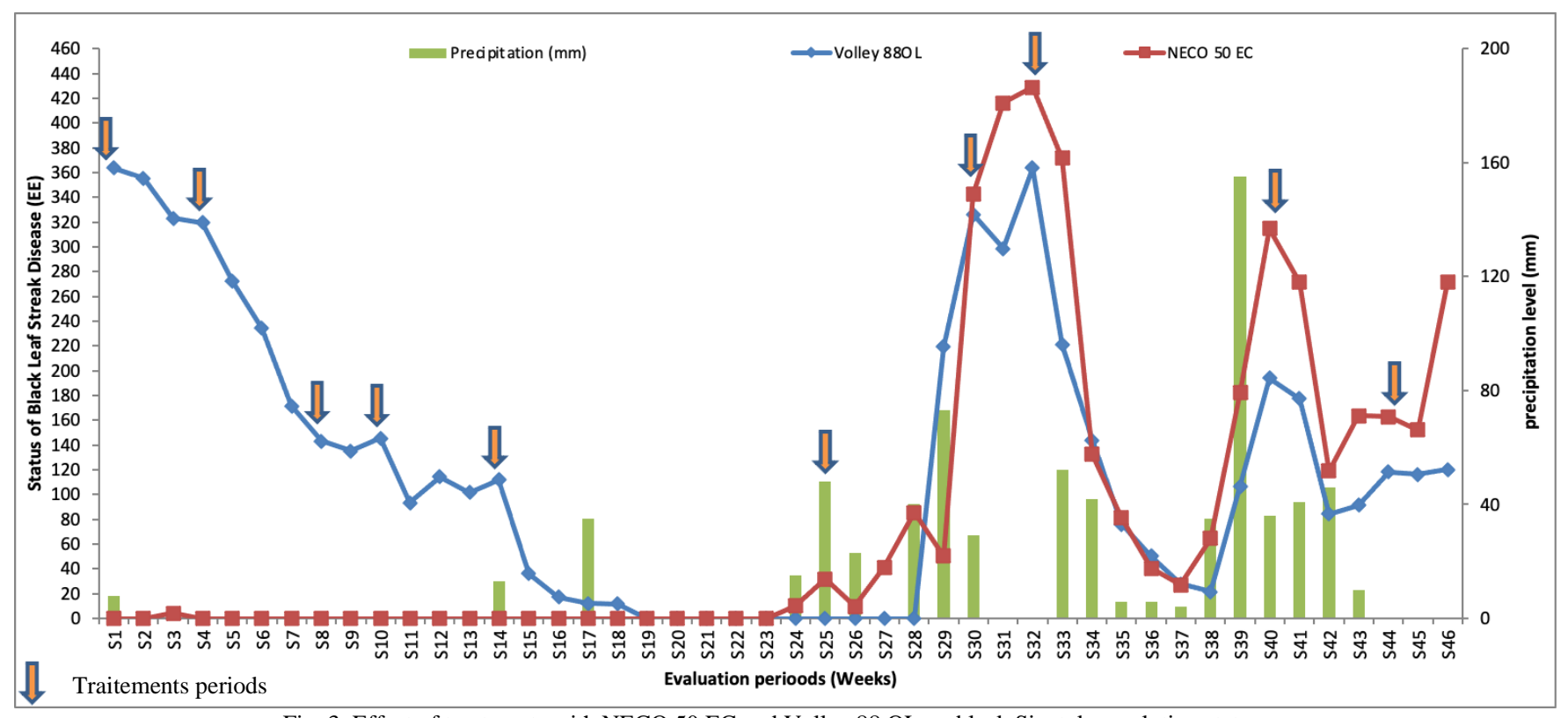

Fig. 3. Effect of treatments with NECO 50 EC and Volley 88 OL on black Sigatoka evolution status.

\section{DISCUSSION}

As part of the search for new active ingredients with a fungitoxic effect for black Sigatoka management in organic banana production, the effect of NECO 50 EC was assessed. Under in vitro condition, after its incorporation into the culture medium, a reduction in Mycosphaerella fijiensis conidia germ tube elongation was observed from $1 \mu \mathrm{l} / \mathrm{l}$ up to total inhibition at $400 \mu \mathrm{l} / \mathrm{l}$. This anti-germinating effect of NECO 50 EC, which is useful for reducing disease spreading, has been demonstrated in several research studies. Thus, [17] have shown its in vitro effectiveness by the total inhibition of the mycelial growth of Colleetotrichum gloeosporioides, cashew tree anthracnose causative agent and Pestalotia heterocornis, another cashew tree pathogen, at the concentration of $300 \mu \mathrm{l} / 1$ and $200 \mu \mathrm{l} / \mathrm{l}$, respectively. The work of [18] also showed that the incorporation of NECO 50 EC in the pea agar culture medium caused a $78.37 \%$ reduction in the mycelial growth of Phytophthora palmivora, the agent causing cocoa pod brown rot, after 4 days of incubation. The antibacterial activity of NECO 50 EC has also been demonstrated in bacterial strains which may or may not produce extended spectrum $\beta$-lactamases [19]. [20] have also demonstrated its bactericidal effect on 
strains of Xanthomonas axonopodis pv. manihotis responsible for cassava bacterial blight. This toxicity of NECO 50 EC for fungal and bacterial pathogens is thought to be linked to the effect of Ocimum gratissimum essential oil, which constitutes its active ingredient. This essential oil has already shown an in vitro inhibitory activity of Mycosphaerella fijiensis conidia germination [21]. By comparing the fungicidal effect of plant essential oils with that of conventional fungicides, it was found that Ocimum gratissimum oil inhibits spore germination and mycelial growth of Fusarium oxysporum f. sp. radicis lycopersici and Pythium sp. with an effect relatively equivalent to that of synthetic fungicides [22], [23]. This ability of Ocimum gratissimum essential oil to reduce the survival of Mycosphaerella fijiensis conidia is probably related to its composition of antifungal elements. Various research studies on its composition agree on the existence of chemotypes, five of which are known: the citral, ethyl cynnamate, eugenol, linalool and thymol types [24]-[31]. These compounds hold a large majority in the essential oil and can reach more than $80 \%$ of terpene compounds [28]. In Côte d'Ivoire, the thymol chemotype has mainly been demonstrated in the compositions of Ocimum gratissimum oil [23], [32]-[34]. The inhibitory activity of NECO 50 EC is probably linked to its high dose of thymol, which constitutes the major phenolic compound of this biopesticide. The work of [35] has shown that the major compounds involved in the biological activity of thyme oil are thymol (90\%) and its isomer carvacrol (8\%). Thymol is believed to be responsible for most of the antifungal activities demonstrated against Venturia inaequalis [36]. It is also believed to be active on other ascomycetes, such as Alternaria alternat [36].

TABLE I: EFFECT OF THE APPLICATION OF NECO 50 EC AND VOLLEY 88 OL ON THE PHYTOPATHOLOGICAL DESCRIPTORS OF BLACK SIGATOKA AND BANANA TREE PRODUCTIVITY FACTORS

\begin{tabular}{|c|c|c|c|c|c|c|c|c|}
\hline & \multicolumn{8}{|c|}{ Average values of black Sigatoka phytopathological descriptors and banana tree productivity factors } \\
\hline & \multicolumn{4}{|c|}{ NECO $50 \mathrm{EC}$} & \multicolumn{4}{|c|}{ VOLLEY 88 OL } \\
\hline & YLA & YLN & NFLF & NFLH & YLA & YLN & NFLF & NFLH \\
\hline S1 & $6.30 \mathrm{a}$ & $9.05 \mathrm{~b}$ & - & - & $3.90 \mathrm{~b}$ & $11.01 \mathrm{a}$ & - & - \\
\hline $\mathrm{S} 2$ & $5.85 \mathrm{a}$ & $9.47 \mathrm{~b}$ & - & - & $3.80 \mathrm{~b}$ & $11.56 \mathrm{a}$ & - & - \\
\hline $\mathrm{S} 3$ & $5.37 \mathrm{a}$ & $9.57 \mathrm{~b}$ & - & - & $3.76 \mathrm{~b}$ & $11.60 \mathrm{a}$ & - & - \\
\hline $\mathrm{S} 4$ & $5.92 \mathrm{a}$ & $10.17 \mathrm{~b}$ & - & - & $3.81 \mathrm{~b}$ & $11.68 \mathrm{a}$ & - & - \\
\hline S5 & $6.46 \mathrm{a}$ & $10.56 \mathrm{~b}$ & - & - & $3.03 \mathrm{~b}$ & $11.68 \mathrm{a}$ & - & - \\
\hline S6 & $6.76 \mathrm{a}$ & $11.24 \mathrm{~b}$ & - & - & $4.28 \mathrm{~b}$ & $12.33 \mathrm{a}$ & - & - \\
\hline S7 & $7.24 \mathrm{a}$ & $11.44 \mathrm{~b}$ & - & - & $4.56 \mathrm{~b}$ & $12.26 \mathrm{a}$ & - & - \\
\hline $\mathrm{S} 8$ & $7.30 \mathrm{a}$ & $11.94 \mathrm{a}$ & - & - & $4.76 \mathrm{~b}$ & $12.83 \mathrm{a}$ & - & - \\
\hline S9 & $8.01 \mathrm{a}$ & $12.11 \mathrm{~b}$ & - & - & $4.80 \mathrm{~b}$ & $13.23 \mathrm{a}$ & - & - \\
\hline S10 & $8.01 \mathrm{a}$ & $12.80 \mathrm{a}$ & - & - & $5.06 \mathrm{~b}$ & $13.13 \mathrm{a}$ & - & - \\
\hline S11 & $8.31 \mathrm{a}$ & $12.48 \mathrm{a}$ & - & - & $5.15 \mathrm{~b}$ & $12.81 \mathrm{a}$ & - & - \\
\hline $\mathrm{S} 12$ & $7.85 \mathrm{a}$ & $12.81 \mathrm{a}$ & - & - & $4.95 \mathrm{~b}$ & $12.61 \mathrm{a}$ & - & - \\
\hline S13 & $8.13 \mathrm{a}$ & $12.80 \mathrm{a}$ & - & - & $5.21 \mathrm{~b}$ & $12.21 \mathrm{a}$ & - & - \\
\hline S14 & $8.03 \mathrm{a}$ & $12.75 \mathrm{a}$ & - & - & $5.06 \mathrm{~b}$ & $12.51 \mathrm{a}$ & - & - \\
\hline S15 & $8.00 \mathrm{a}$ & $13.33 \mathrm{a}$ & - & - & $5.66 \mathrm{~b}$ & $12.83 \mathrm{a}$ & - & - \\
\hline S16 & $8.75 \mathrm{a}$ & $12.48 \mathrm{a}$ & $13.13 \mathrm{a}$ & - & $6.33 \mathrm{~b}$ & $13.06 \mathrm{a}$ & $13.25 \mathrm{a}$ & - \\
\hline S17 & $8.48 \mathrm{a}$ & $13.13 \mathrm{a}$ & $13.53 \mathrm{a}$ & - & $7.15 \mathrm{~b}$ & $13.25 \mathrm{a}$ & $13.15 \mathrm{a}$ & - \\
\hline S18 & $9.10 \mathrm{a}$ & $13.15 \mathrm{a}$ & $13.48 \mathrm{a}$ & - & $7.51 \mathrm{~b}$ & $13.53 \mathrm{a}$ & $13.26 \mathrm{a}$ & - \\
\hline S19 & $9.38 \mathrm{a}$ & $13.48 \mathrm{a}$ & $13.83 \mathrm{a}$ & - & $7.80 \mathrm{~b}$ & $13.26 \mathrm{a}$ & $13.61 \mathrm{a}$ & - \\
\hline S20 & $9.05 \mathrm{a}$ & $13.83 \mathrm{a}$ & $13.73 \mathrm{a}$ & - & $8.36 \mathrm{a}$ & $13.61 \mathrm{a}$ & $13.51 \mathrm{a}$ & - \\
\hline $\mathrm{S} 21$ & $9.13 \mathrm{a}$ & $13.75 \mathrm{a}$ & $14.08 \mathrm{a}$ & - & $8.96 \mathrm{a}$ & $13.51 \mathrm{a}$ & $13.93 \mathrm{a}$ & - \\
\hline $\mathrm{S} 22$ & $9.45 \mathrm{a}$ & $14.08 \mathrm{a}$ & $13.85 \mathrm{a}$ & - & $9.45 \mathrm{a}$ & $13.93 \mathrm{a}$ & $13.93 \mathrm{a}$ & - \\
\hline $\mathrm{S} 23$ & $9.61 \mathrm{a}$ & $13.85 \mathrm{a}$ & $13.90 \mathrm{a}$ & - & $9.58 \mathrm{a}$ & $13.93 \mathrm{a}$ & $13.95 \mathrm{a}$ & - \\
\hline $\mathrm{S} 24$ & $7.55 \mathrm{~b}$ & $13.90 \mathrm{a}$ & $13.16 \mathrm{a}$ & - & $9.33 \mathrm{a}$ & $13.95 \mathrm{a}$ & $13.40 \mathrm{a}$ & - \\
\hline $\mathrm{S} 25$ & $6.96 \mathrm{~b}$ & $13.16 \mathrm{a}$ & $11.18 \mathrm{~b}$ & - & $8.18 \mathrm{a}$ & $13.40 \mathrm{a}$ & $12.96 \mathrm{a}$ & - \\
\hline S26 & $6.60 \mathrm{~b}$ & $11.18 \mathrm{~b}$ & $12.28 \mathrm{a}$ & - & $8.31 \mathrm{a}$ & $12.96 \mathrm{a}$ & $13.18 \mathrm{a}$ & - \\
\hline S27 & $6.26 \mathrm{~b}$ & $12.28 \mathrm{a}$ & $11.70 \mathrm{~b}$ & - & $8.16 \mathrm{a}$ & $13.18 \mathrm{a}$ & $13.46 \mathrm{a}$ & - \\
\hline S28 & $5.96 \mathrm{~b}$ & $11.70 \mathrm{~b}$ & $11.30 \mathrm{~b}$ & $6.71 \mathrm{~b}$ & $7.33 \mathrm{a}$ & $13.46 \mathrm{a}$ & $13.00 \mathrm{a}$ & $9.08 \mathrm{a}$ \\
\hline S29 & $4.81 \mathrm{~b}$ & $11.30 \mathrm{~b}$ & $12.16 \mathrm{~b}$ & $6.58 \mathrm{~b}$ & $6.60 \mathrm{a}$ & $13.00 \mathrm{a}$ & $13.25 \mathrm{a}$ & $9.26 \mathrm{a}$ \\
\hline $\mathrm{S} 30$ & $4.30 \mathrm{a}$ & $12.16 b$ & $11.85 \mathrm{~b}$ & $6.46 \mathrm{~b}$ & $4.50 \mathrm{a}$ & $13.25 \mathrm{a}$ & $13.31 \mathrm{a}$ & $9.55 \mathrm{a}$ \\
\hline S31 & $4.16 \mathrm{~b}$ & $11.85 \mathrm{~b}$ & $11.30 \mathrm{a}$ & $6.50 \mathrm{~b}$ & $4.46 \mathrm{a}$ & $13.31 \mathrm{a}$ & $12.00 \mathrm{a}$ & $9.70 \mathrm{a}$ \\
\hline $\mathrm{S} 32$ & $4.25 \mathrm{a}$ & $11.30 \mathrm{a}$ & $11.43 \mathrm{~b}$ & $6.51 \mathrm{~b}$ & $4.45 \mathrm{a}$ & $12.00 \mathrm{a}$ & $12.56 \mathrm{a}$ & $9.85 \mathrm{a}$ \\
\hline S33 & $4.33 \mathrm{a}$ & $11.43 \mathrm{~b}$ & $11.66 \mathrm{~b}$ & $6.71 \mathrm{~b}$ & $4.66 \mathrm{a}$ & $12.56 \mathrm{a}$ & $12.71 \mathrm{a}$ & $10.05 \mathrm{a}$ \\
\hline S34 & $4.96 \mathrm{a}$ & $11.66 \mathrm{~b}$ & $11.73 \mathrm{~b}$ & $6.75 \mathrm{~b}$ & $4.98 \mathrm{a}$ & $12.71 \mathrm{a}$ & $12.81 \mathrm{a}$ & $9.91 \mathrm{a}$ \\
\hline S35 & $5.38 \mathrm{a}$ & $11.73 b$ & $12.46 \mathrm{a}$ & $7.06 \mathrm{~b}$ & $5.23 \mathrm{a}$ & $12.81 \mathrm{a}$ & $12.78 \mathrm{a}$ & $9.78 \mathrm{a}$ \\
\hline S36 & $5.43 \mathrm{a}$ & $12.46 \mathrm{a}$ & $12.30 \mathrm{a}$ & $7.23 \mathrm{~b}$ & $5.41 \mathrm{a}$ & $12.78 \mathrm{a}$ & $12.30 \mathrm{a}$ & $9.81 \mathrm{a}$ \\
\hline S37 & $5.56 \mathrm{a}$ & $12.30 \mathrm{a}$ & $12.48 \mathrm{a}$ & $7.11 \mathrm{~b}$ & $5.50 \mathrm{a}$ & $12.30 \mathrm{a}$ & $12.71 \mathrm{a}$ & $9.70 \mathrm{a}$ \\
\hline S38 & $5.70 \mathrm{a}$ & $12.48 \mathrm{a}$ & $12.73 \mathrm{a}$ & $6.75 \mathrm{~b}$ & $5.78 \mathrm{a}$ & $12.71 \mathrm{a}$ & $12.83 \mathrm{a}$ & $9.71 \mathrm{a}$ \\
\hline S39 & $5.26 \mathrm{a}$ & $12.73 \mathrm{a}$ & $11.81 \mathrm{~b}$ & $6.38 \mathrm{~b}$ & $5.56 \mathrm{a}$ & $12.83 \mathrm{a}$ & $12.51 \mathrm{a}$ & $9.33 \mathrm{a}$ \\
\hline $\mathrm{S} 40$ & $4.66 \mathrm{a}$ & $11.81 \mathrm{~b}$ & $11.78 \mathrm{~b}$ & $6.50 \mathrm{~b}$ & $4.88 \mathrm{a}$ & $12.51 \mathrm{a}$ & $12.60 \mathrm{a}$ & $9.10 \mathrm{a}$ \\
\hline S41 & $4.68 \mathrm{a}$ & $11.78 \mathrm{~b}$ & $12.16 \mathrm{~b}$ & $6.70 \mathrm{~b}$ & $5.00 \mathrm{a}$ & $12.60 \mathrm{a}$ & $12.73 \mathrm{a}$ & $9.21 \mathrm{a}$ \\
\hline S42 & $4.98 \mathrm{a}$ & $12.16 \mathrm{~b}$ & $12.13 \mathrm{a}$ & $6.45 \mathrm{~b}$ & $5.28 \mathrm{a}$ & $12.73 \mathrm{a}$ & $12.01 \mathrm{a}$ & $8.91 \mathrm{a}$ \\
\hline S43 & $5.11 \mathrm{a}$ & $12.13 \mathrm{a}$ & $11.48 \mathrm{a}$ & $6.46 \mathrm{~b}$ & $5.08 \mathrm{a}$ & $12.01 \mathrm{a}$ & $11.40 \mathrm{a}$ & $8.35 \mathrm{a}$ \\
\hline S44 & $5.00 \mathrm{a}$ & $11.48 \mathrm{a}$ & $11.61 \mathrm{a}$ & $6.51 \mathrm{~b}$ & $5.15 \mathrm{a}$ & $11.40 \mathrm{a}$ & $11.53 \mathrm{a}$ & $8.28 \mathrm{a}$ \\
\hline S45 & $5.06 \mathrm{a}$ & $11.61 \mathrm{a}$ & $11.56 \mathrm{a}$ & $6.51 \mathrm{~b}$ & $5.20 \mathrm{a}$ & $11.53 \mathrm{a}$ & $11.76 \mathrm{a}$ & $8.26 \mathrm{a}$ \\
\hline S46 & $4.76 \mathrm{a}$ & $11.56 \mathrm{a}$ & $11.50 \mathrm{a}$ & $6.51 \mathrm{~b}$ & $5.11 \mathrm{a}$ & $11.76 \mathrm{a}$ & $11.70 \mathrm{a}$ & $8.26 \mathrm{a}$ \\
\hline
\end{tabular}

For the same parameters of both treatments, the averages followed by the same letter are not significantly different at $\alpha=0.05$. YLA (Youngest leaf affected); YLN (Youngest necrotic leaf); NFLF (Number of functional leaves at flowering); NFLH (Number of functional leaves at harvest). 
On culture media amended with synthetic fungicides, Mycosphaerella fijiensis conidia behaved differently. Pyraclostrobin caused a complete reduction in germ tube elongation. In contrast, the reduction in germination with the amendments to propiconazole and fenpropimorph was 63.10 $\mathrm{pc}$ and $51.20 \mathrm{pc}$, respectively. According to the recommendations of the FRAC [37], the laboratory threshold for declaring resistance was set, for propiconazoles (triazoles), at $65 \mathrm{pc}$ of germ tube reduction rate and $75 \mathrm{pc}$ for fenpropimorph (morpholines) for the dose of $0.1 \mu \mathrm{l} / \mathrm{L}$. A loss of sensitivity of the conidia is therefore observed for these last two active ingredients. Adaptation to fungicides by the loss of effectiveness of certain products used for chemical control such as benzimidazoles and triazoles has already been reported [38]. For pyraclostrobin (strobulirin), the reduction was complete. This synthetic fungicide was most effective in in vitro tests and no resistance could be developed by Mycosphaerella fijiensis conidia. These results corroborate those of [39] who have shown that fungicides of the strobilurin family have proved to be more effective in combating leaf lesions than propiconazole and mancozeb.

Aerial spraying of NECO $50 \mathrm{EC}$ and Volley $88 \mathrm{OL}$ in industrial banana tree plantation showed a significant effect on the evolution of the main descriptors of black Sigatoka and banana tree productivity factors. The average rank of the youngest leaf affected (YLA) ranged from 4.16 to 9.61 and from 3.03 to 9.58 on the plots treated with NECO 50 EC and Volley $88 \mathrm{OL}$, respectively. These applications delayed the onset of the early stages of the disease while protecting the new leaves generated by bananas trees. Similar results were obtained in the work of [40] on Fluopyram on-farm biological effectiveness in the management of Sigatoka disease in banana trees. The first stages of the disease (streaks) were observed on the leaves of rank 4 and 5 for the plots treated with Fluopyram. This ability of NECO 50 EC to protect plant organs was demonstrated during the work of [18]. These authors have shown that the application of NECO 50 EC to cocoa pods inoculated with a fungal suspension of Phytophthora palmivora delayed the onset of brown rot symptoms on pods. According to [20], the application of NECO $50 \mathrm{EC}$ at $5 \mathrm{ml} / \mathrm{l}$ during periods of high parasite pressure significantly reduced the severity of cassava bacterial blight. The lowest YLA ranks, located between 4.16 and 4.98, on the plots treated with NECO 50 EC were observed between weeks 29 and 42 corresponding to the weeks with the highest humidity. The effect of humidity on the increased parasite pressure of Mycosphaerella fijiensis is demonstrated in the work of [41].

The average rank of the youngest necrotic leaf (YLN) varied from 9.05 to 14.08 and from 11.01 to 13.95 on the plots treated with NECO 50 EC and Volley 88 OL, respectively. The applications therefore prevented a quick evolution of the symptoms from streak to necrosis stage and conferred partial resistance to banana trees, especially since in the hybrid CRBP-39, recognized to be resistant to black Sigatoka, the average values of the YLN were 13.44 at the sixth month after planting [42].

A drop in the amplitude of black Sigatoka evolution status curve was observed with each application of NECO 50 EC. This result would suggest that NECO 50 EC exerts a direct inhibitory effect on Mycosphaerella fijiensis spores found on the first 4 leaves taken into account when calculating disease evolution status. This drop persisted for 5 successive weeks after certain treatments, despite the humidity favorable to reducing the incubation period of the fungus (13 to 14 days). In addition to its direct effect, NECO $50 \mathrm{EC}$ might also exert an indirect effect through the mobilization of secondary metabolites by the treated banana trees. Generally, the relationship between an accumulation of conjugated compounds and the resistance induced in certain plants has already been well established in other pathosystems and is suggested to be a necessary component for the host's defensive response [43], [44]. The eliciting effect of Ocimum gratissimum leaf extracts, a component of NECO $50 \mathrm{EC}$, has been demonstrated in sorghum and soybean respectively by inducing the production of deoxyanthocyanidins and phytoalexins [45]. The involvement of proanthocyanidins in the partial resistance of some banana trees has been revealed by [46], [47]. In addition to its anti-germinating and preventive effect against black Sigatoka, the application of NECO 50 EC had a significant effect on the productivity parameters of the treated banana trees. It maintained at least 11.18 functional leaves at flowering and 6.38 functional leaves at harvest. Less significant results were obtained in the cultivar Yangambi Km 5 described as tolerant to black Sigatoka [48]. At flowering stage, the vegetative growth of banana trees stops and a minimum number of 8 functional leaves is required for good bunch development and quality fruit [49]. The number of functional leaves at harvest (6.38 leaves) is within the standards of 4 to 5 leaves usually required for export in order to limit disease effects on banana ripening. Some trials have also shown that bunch weight is little affected when the number of functional leaves between flowering and harvest is between 5 and 7 [50]. Treatment with NECO 50 EC could ensure from flowering to harvest, good bunch filling and sufficient green life for banana transportation.

\section{CONCLUSION}

Reducing the use of chemical inputs in the production of dessert bananas in Côte d'Ivoire would be an asset for its competitiveness on international markets. The management of black Sigatoka, a major constraint in banana cultivation can validly be ensured by NECO 50 EC. This plant extractbased biofungicide has a low-dose anti-germinating effect on Mycosphaerella fijiensis conidia, useful in reducing disease spreading. Its implementation in an integrated pest management system associated with mechanical sanitation has protected the new leaves generated by banana trees and prevented a quick progression of symptoms from streak to necrosis stage. During flowering and harvest, the use of NECO 50 EC maintained a sufficient number of functional leaves for good bunch filling and a fairly long green life.

Foliar spraying of NECO $50 \mathrm{EC}$ at 0.3 1/ha showed similar effectiveness to that of Volley $88 \mathrm{OL}$ at a dose of $0.5 \mathrm{l} / \mathrm{ha}$.

\section{ACKNOWLEDGMENT}

We are grateful to the managers of the industrial banana tree plantations of BBSA (Côte d'Ivoire) for having granted 
access to the different plantations under their responsibility for carrying out this study.

\section{CONFLICT OF INTEREST}

The authors declared no conflict of interest.

\section{REFERENCES}

[1] P. Lepoivre, "Phytopathologie : bases moléculaires et biologiques des pathosystèmes et fondements des stratégies de lutte". Bruxelles: De Boeck; Gembloux: les Presses agronomiques de Gembloux, Vol. 1427 p. 2003.

[2] C. Pasberg-gauhl and F. Gauhl, "Response to east African Highland Bananas to black leaf streak sigatoka and Cladosporium leaf speckle under tropical humid forest and conditions in West Africa". In: Banana and Plantain for Africa. K. Craenen et al (Eds). Proc. I. Int. Symp Acta Hort. 540 p. 2000.

[3] X. Mourichon and A. Fullerton. "Dévéloppement de Mycosphaerella musicola (maladie de Sigatoka) et Mycosphaerella fijiensis (maladie des raies noires). Etude du cas particulier des productions d'altitude". Fruits, 45 (1): 17-24. 1990.

[4] E.B Sidoine, D.K.E. Brice, T. Siaka, K.A. Michel, N. Boni, K. Kouman and K. Daouda, "Phytosanitary status in industrial banana plantations in the fight against black leaf streak disease in Côte d'Ivoire," Eur. Sci. J., 16: 393-409. 2020.

[5] M. Chillet, C. Abadie, O. Hubert, Y. Chilin-Charles, L. de Lapeyre de Bellaire, "Sigatoka disease reduces the green life of bananas". Crop Protection, 28 (1): 41-45, 2009.

[6] B. Essis, K. Kobenan, S. Traoré, D. Koné and J. Yatty, "Laboratory sensitivity of Mycosphaerella fijiensis responsible for black cercosporiosis of banana trees to fungicides commonly used in banana plantations in Côte d'Ivoire". J. Anim. Plant Sci., 7: 822-833. 2010.

[7] FIRCA, "Stratégie pluriannuelle pour la période 2012-2013", Côte d'Ivoire, 27 p. 2010.

[8] K. C. Bempah., A. Buah-Kwofie, E. Enimil, B. Blewu et G. AgyeiMartey. "Residues of organochlorine pesticides in vegetables marketed in Greater Accra Region of Ghana" Food Control, n²5, pp. 537-542, 2012.

[9] J. Baudry, P. Pointereau, L. Seconda, R. Vidal, B. Taupier-Letage, B. Langevin, "Improvement of diet sustainability with increased level of organic food in the diet: findings from the BioNutriNet cohort". The American Journal of Clinical Nutrition 109(4): 1173-1188, 2019.

[10] S. Bellon, S. Penvern. "Organic food and farming as a prototype for sustainable agricultures". Dordrecht: Springer, pp. 1-19. 2014.

[11] L. Brureau, E. Emeville, C. Helissey, JP. Thome, L. Multigner, P. Blanchet. "Endocrine disrupting-chemicals and biochemical recurrence of prostate cancer after prostatectomy: A cohort study in Guadeloupe (French West Indies)" International Journal of Cancer, 146(3): 657-663. 2019. DOI: 10.1002/ijc.32287.

[12] C.L. Cantrel, F.E. Dayan \& S. O. Duke Natural products as sources for new pesticide. Journal of natural products, 75 (6): 1231- 42. 2012.

[13] J.M. Risède, T. Lescot, J.C. Cabrera, M. Guillon, K. Tomekpé, H.J Gert, F. Kema. "Nouvelles stratégies à court et moyen termes pour réduire l'utilisation des pesticides dans les cultures de bananes. De la théorie à la pratique, Étude de Cas sur la Banane" - Guide Numéro 1. www.endure-network.eu 2010.

[14] E. Fouré. "Les cercosporioses du bananier et leurs traitements. Sélection de molécules fongicides nouvelles". Fruits, 38 (1): 21-34. 1983.

[15] R.H Stover. \& J.D Dickson. "Leaf of banana caused by Mycosphaerella musicola: methods of measuring spotting prevalence and severity". Tropical Agriculture, 47: 289-302. 1970.

[16] Anonyme 1. "Liste des pesticides homologués au Cameroun, liste réservée au grand public". 212 p Avril 2019.

[17] N. Silué, K. Abo, F. Johnson, B. Camara, M. Koné, D. Koné, 2018. "Évaluation in vitro et in vivo de trois fongicides de synthèse et d'un fongicide biologique sur la croissance et la sévérité de Collétotrichum gloeosporioides et de Pestalotia heterornis, champignons responsables de maladies foliaires de l'anacardier (Anacardium occidentale L.)" Agronomie Africaine 30 (1) : 107-122. 2018.

[18] B. Fofana, S. Soro, F. Kassy, N. Silué, M. Zouzou and D. Kone. "Valorization of biofungicides of plant origin for an eco-efficient management of the brown rot of cocoa pods caused by Phytophthora palmivora," Journal of Animal \& Plant Sciences, Vol.44 (2): 76547676. 2020.
[19] J.-F. Yala, M.R. Mabika, B. Camara, A. Souza, A.N. Lepengue, S. Tuo, D. Koné and B. M'batchi. In vitro antibacterial activity of Cymbopogon citratus, Eucalyptus citriodora, Lippia multiflora, Melaleuca quinquenervia essential oils and Necoß on extended spectrum $\beta$ lactamases producing or non-producing bacterial strains. Vol. 10(43), pp. 796-804, 17 November, 2016 DOI: 10.5897/JMPR2016.6272.

[20] A.M. Affery, K. Abo, I. Wonni, S. Tuo, F.M. Kassi, B. Camara and D. Koné. "Assessment of the NECO's effectiveness against cassava bacterial blight caused by Xanthomonas axonopodis pv. manihotis In Côte d'Ivoire". Int. J. Agric. Res., 12: 190-198. 2017.

[21] D. Kone, S. Tuo, E. Amari, S. Traoré, J-P. Lorgn et E. Kouakou. "Activité antifongique in vitro de Ocimun gratissimum $\mathrm{L}$. et de Melaleuca quinquenervia sur Mycosphaerella fijiensis Morelet, responsable de la cercosporiose noires des bananiers (Musa spp.)". June 2015. Conférence: SEMINAIRE DIVECOSYS (Diversité des systèmes de production et gestion agro-écologique des bio-agresseurs en Afrique de l'Ouest), Protection durable des cultures: Quels leviers actionner? At: Dakar, Sénégal.

[22] M. Doumbouya, K. Abo, A.N. Lepengue, B. Camara, K. Kanko, D. Aidara, D. Kone. "Activités comparées in vitro de deux fongicides de synthèse et de deux huiles essentielles, sur des champignons telluriques des cultures maraichères en Côte d'Ivoire". J. Appl. Biosci., 50, 35203532. 2012.

[23] K. F. J-M Kassi, K. G. Kouame, K. Kouame, B. B. A. Bolou \& D. Kone. "Chemical composition of the essential oil extracted from the fresh leaves of Ocimum gratissimum and evaluation of its fungitoxicity on 3 isolates of Fusarium oxysporum lycopersici, telluric parasite in tomato culture". Afrique SCIENCE 16(1), 226-237 2020.

[24] L. Jirovertz, G. Buchbauer \& M.B. Ngassoum. "Investigation of the essential oils from the dried fruits of Xylopia aethiopica (West African "peppertree") and Xylopia parviflora from Cameroon". Ernahrung, 21 (7-8): 324-325 1997.

[25] K. Cimangam, S. Apers, D.T. Bruyne, V.S. Miert, N. Hermans, J. Totté, L. Pieters, A.J. Vlietinck, K. Kambu \& L. Tona. "Chemical composition and antifungal activity of essential oil of some aromatic medicinal plants growing in the Democratic Republic of Congo". Journal of Essential Oil Research, 14: 382- 387. 2002.

[26] S.C. Gupta. "Variation in herbage yield, oil yield and major component of various Ocimum species/varieties (chemotypes) harvested at different stages of maturity". Journal of Essential Oil Research, 8: 275279. 1996

[27] Y. Mohammed, B. Jaripa, L. Mondello \& I.S. D'Alcontes. "Studies on the essential oil-bearing plants of Bangladesh. Part VI. Composition of the oil of Ocimum gratissimum L." Flavour and Fragrance Journal, 13 (3): 163-166. 1998.

[28] A.K. Pandey, A.R. Chowdhury, K. Sushil, D. Samresh, A.K. Kukreja, S. Ashok, A.K. Singh, S. Srikant \& T. Rakesh. "Composition of the essential oil of Ocimum gratissimum grown in Madhya Pradesh. Proceedings of the National Seminar on the Frontiers of Research and Development in Medicinal Plants. Lucknow, India, 16-18 Semtember 2000". Journal of Medicinal and Aromatic Plants Sciences, 22-23 (4A1A), 26-2. 2001

[29] D.A.G. Cortez, L.E.R. Cortez, G.L. Pessini, D.L.Doro \& C.V. Nakamura . "Analysis of essential oil of alfavaca Ocimum gratissimum L. (Labiatae)". Orquivos de Ciencias da Saude da UNIPAR, 2 (2): 125127. 1998

[30] D.D. Medici, S. Pieretti, G. Salvatore, M. Nicoletti \& P. Rasoanaivo P. "Chemical analysis of essential oils of malagasy medicinal plants by gaz chromatography and NMR spectrocsopy". Flavour and Fragrance Journal, 7: 275-281. 1992.

[31] H. Kouninki, T.F.A. Hance, F.A. Noudjou, G. Lognay, F. Malaisse, M.B. Ngassoum, P.M. Mapongmetsem, T.L.S. Ngamo \& E. Haubruge. "Toxicity of some terpenoids of essential oils of Xylopia aethiopica from Cameroon against Sitophilus zeamais Motschulsky". Journal of Applied Entomology, 131 (4): 269- 274. 2007

[32] K.C. Kobenan, V.E. Tia, G.E.C. Ochou, M. Kouakou and K.K.N. Bini. "Comparison of the insecticidal potential of essential oils of Ocimum gratissimum L. and Ocimum canum Sims on Pectinophora gossypiella Saunders (Lepidoptera: Gelechiidae), an insect pest of cotton trees in Côte d'Ivoire". Eur. Sci. J., 14: 286-301. 2018.

[33] C. Kanko, R.K. Oussou, J. Akcah, J.B. Boti, B.P. Seri-Kouassi and J. Casanova, "Structure of the majority compounds and insecticidal activity of essential oils extracted from seven aromatic plants in Côte d'Ivoire". Int. J. Eng. Appl. Sci., 4: 27-34. 2017.

[34] A.M Koffi, Z.F. Tonzibo, L. Delort, N. Ruiz, L. Caldefie-Chézet and J.C. Chalchat "Correlation between the chemical composition and antifungal activity of thymol-dominant essential oils on Candida albicans and Aspergillus fumigatus." Phytothérapie, 11: 134-139. 2013. 
[35] R. Thiesz, A. Balog, L. Ferencz, et A. Júlia. "The effects of plant extracts on apple scab (Venturia inaequalis Cooke) under laboratory conditions". Romanian Biotechnological Letters. 2007. Vol. 12, $\mathrm{n}^{\circ} 4$, pp. 3295. 2007.

[36] F. J. Perina, D. C Amaral, R. S Fernandes, C. R. Labory, G. A Teixeira, and E. Alves. "Thymus vulgaris essential oil and thymol against Alternaria alternata (Fr.) Keissler: effects on growth, viability, early infection and cellular mode of action." Pest Manag. Sci., vol. 71, pp. 1371-8. 2015.

[37] S. Knight, M. Wirz, A. Amil \& M. Shaw. "The role of managing resistance to fungicides in maintaining the effectiveness of integrated strategies to control black leaf streak disease. In: Jacombe L, Lepoivre P, Marin D, Ortiz R, Romero R, Escalant JV (Eds) Mycosphaerella Leaf Spot of Bananas: Present Status and Outlook, Proceedings of the 2nd International Workshop on Mycosphaerella Leaf Spot Diseases, 20-23 May 2002.INIBAP, Montpellier, France, pp 303-307.

[38] G. Martinez, J. Hernández, O. Tremont, R. Pargas, E. Manzanilla. "The spread of black Sigatoka throughout Venezuela, 1997-2000". Infomusa, 11 (1), 6-9. 2002.

[39] L. Lynton, Vawgrey \& G. Kathy. "Evaluation en champ de l'action des strobilurines, des triazoles et de l'acibenzolar pour lutter contre la maladie de Sigatoka en Australie”. InfoMusa, 14 (2):14 p. 2005.

[40] H. S. Gueu, T. K. Kouakou, J. Pohé, E. O. Tienébo. "Contribution à la Gestion des Cercosporioses du bananier dues à Mycosphaerella spp. par l'utilisation du Fluopyram associé à l'huile minérale en Côte d'Ivoire". Journal of Applied Biosciences, 113: 11158-11173 2017.

[41] F. Jimenez, F. Tapia, A. C. Gribuis, N. Escalant, J.-V. Catie. "Relation entre la durée de pluie et le développement de la cercosporiose noire sur le bananier plantain. Proposition d'un système d'avertissement biométéorologique". Fruits, 50(2), 87-99. Consulté à l'adresse https://revues.cirad.fr/index.php/fruits/article/view/35464 1995.

[42] J-P. Cohan C. Abadie, K. Tomekpé, T.J. Tchango. "Performances agronomiques et résistance à la maladie des raies noires de l'hybride 'CRBP-39'”. Infomusa (Ed. Française), 12 (1) : 29-32. 2003.

[43] M. Ongena, F. Daayf, P. Jacques, P. Thonart \& N. Benhamou. "Systemic induction of phytoalexins in cucumber in response to treatments with fluorescent Pseudomonas". Plant Pathology, 49: 52330. 2000 .

[44] L.D.G.E. Amari. "Stratégies d'évaluation et de gestion par stimulation des défenses naturelles des bananiers à l'infection de la maladie des raies noires causée par Mycosphaerella fijiensis Morelet (Mycosphaerellacées) en Côte d'Ivoire". Thèse Unique de Doctorat en Physiologie Végétale, Université Félix HOUPHOUÊT-BOIGNY. (2012).

[45] F.T. Colpas, K.R.F. Schwan-Estrada, J. R. Stangarlin, M.L. Ferrarese, C.A. Scapim \& S.M. Bonaldo. "Induction de réponses de défense des plantes par des extraits de feuilles d'Ocimum gratissimum L. (Lamiaceae)". Summa Phytopathologica, 35 (3): 191-195. 2009.

[46] A. Bévéraggi, X. Mourichon, G. Sallé. "Étude comparée des premières étapes de l'infection chez les bananiers sensibles et résistants infectés par le Cercospora fijiensis (Mycosphaerella fijiensis) agent responsable de la maladie des raies noires". Canadian Journal of Botany, 73: 1328-1337. 1995. https://doi.org/10.1139/b95-144.

[47] A. El Hadrami. "Proanthocyanidines constitutives des feuilles de bananiers et résistance partielle vis-à-vis de Mycosphaerella fijiensis, l'agent causal de la maladie des raies noires. Mémoire" : Faculté universitaire des Sciences agronomiques de Gembloux (Belgique) 1997.

[48] K. Mobambo. "Stratégie de gestion intégrée de culture pour la production de bananier plantain et le contrôle de la cercospiose en République Démocratique du Congo" Infomusa, 11:3-6 2002.

[49] G.A. Martinez. "Determinacion del area minima foliar en platano en el tropico hmedo". Revista ICA, 19 (2): 183-187. 1984.

[50] A. Vargas, M. Araya, M. Guzman. and G. Murillo. "Effect of leaf pruning at flower emergence of banana plants (Musa AAA) on fruit yield and black Sigatoka (Mycosphaerella fijiensis) disease", Int. J. Pest Manag., 55:19-25. 2009. 